Nana Xin, Jun Zheng and Qingpeng $\mathrm{He}^{\star}$

\title{
The crystal structure of $\boldsymbol{N}, \boldsymbol{N}^{\prime}$-(Disulfanediyldi- 2,1-phenylene)di(6'-methylpyridine)- 2-carboxamide, $\mathrm{C}_{26} \mathrm{H}_{22} \mathrm{~N}_{4} \mathrm{O}_{2} \mathrm{~S}_{2}$
}

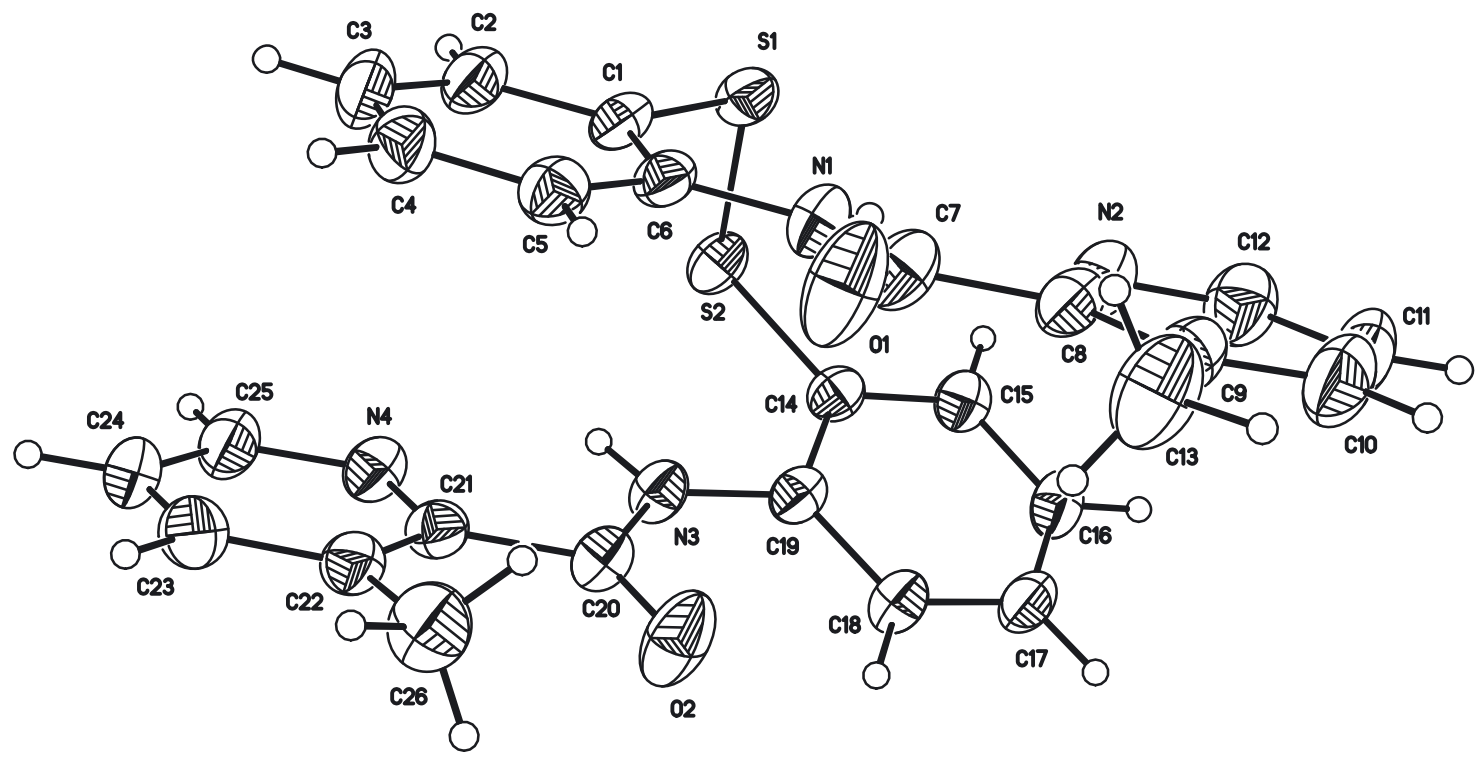

https://doi.org/10.1515/ncrs-2021-0206

Received May 24, 2021; accepted June 28, 2021;

published online July 14, 2021

\section{Abstract}

$\mathrm{C}_{26} \mathrm{H}_{22} \mathrm{~N}_{4} \mathrm{O}_{2} \mathrm{~S}_{2}$, triclinic, $P \overline{1}$ (no. 2), $a=7.9495(7) \AA$, $b=11.2494(12) \AA, c=13.7829(13) \AA, \alpha=81.433(2)^{\circ}$, $\beta=76.536(1)^{\circ}, y=82.641(2)^{\circ}, V=1179.7(2) \AA^{3}, Z=2$, $R_{g t}(\mathrm{~F})=0.0727, w R_{\text {ref }}\left(F^{2}\right)=0.2189, \mathrm{~T}=298(2) \mathrm{K}$.

\section{CCDC no.: 2092800}

The molecular structure is shown in the figure. Table 1 contains crystallographic data and Table 2 contains the list of the atoms including atomic coordinates and displacement parameters.

\footnotetext{
*Corresponding author: Qingpeng He, School of Chemistry and Chemical Engineering, Liaocheng University, Liaocheng 252000, Shandong, China, E-mail: heqingpenglc@163.com

Nana Xin and Jun Zheng, School of Chemistry and Chemical Engineering, Liaocheng University, Liaocheng 252000, Shandong, China
}

Ә Open Access. @ 2021 Nana Xin et al., published by De Gruyter. (c) BY License.
Table 1: Data collection and handling.

\begin{tabular}{ll}
\hline Crystal: & Yellow block \\
Size: & $0.23 \times 0.21 \times 0.20 \mathrm{~mm}$ \\
Wavelength: & Mo $K \alpha$ radiation $(0.71073 \AA)$ \\
$\mu:$ & $0.26 \mathrm{~mm}^{-1}$ \\
Diffractometer, scan mode: & Bruker SMART APEX II, $\varphi$ and $\omega$ \\
$\theta_{\max }$, completeness: & $25.0^{\circ}, 98 \%$ \\
$N\left(h k l_{\text {measured }}, N\left(h k l l_{\text {unique }}, R_{\text {int: }}:\right.\right.$ & $6008,4109,0.067$ \\
Criterion for $I_{\text {obs }}, N\left(h k l_{\text {gt }}:\right.$ & $I_{\text {obs }}>2 \sigma\left(I_{\text {obs }}\right), 2424$ \\
$N(\text { param })_{\text {refined }}:$ & 309 \\
Programs: & Bruker [1], SHELX [2] \\
\hline
\end{tabular}

\section{Source of material}

In the typical case, 6-methyl-2-pyridinecarboxylic acid (1.2 mmol), $N$-methyl morpholine $(0.4 \mathrm{mmol})$, and ethylchloroformate $(0.4 \mathrm{mmol})$ were successively added to the $10 \mathrm{~mL}$ dry tetrahydrofuran (THF) and stirred at $-15^{\circ} \mathrm{C}$ for $20 \mathrm{~min}$. After $20 \mathrm{~min}$ of stirring, 2-(2-(2-aminophenyl) disulfanyl)-benzenamine $(0.3 \mathrm{mmol})$ was added to the solution, and the reaction mixture was stirred for $2 \mathrm{~h}$ at $-15^{\circ} \mathrm{C}$. The stirring was later continued at room temperature for an additional $12 \mathrm{~h}$. The reaction was monitored by using thin 
Table 2: Fractional atomic coordinates and isotropic or equivalent isotropic displacement parameters $\left(\AA^{2}\right)$.

\begin{tabular}{|c|c|c|c|c|}
\hline Atom & $x$ & $y$ & $z$ & $U_{\text {iso }} * / U_{\text {eq }}$ \\
\hline N1 & $0.7177(5)$ & $0.7664(3)$ & $0.2043(3)$ & $588(10)$ \\
\hline $\mathrm{H} 1$ & 0.670456 & 0.716123 & 0.253320 & $0.071^{*}$ \\
\hline $\mathrm{N} 2$ & $0.6380(6)$ & $0.5491(4)$ & $0.2069(3)$ & $0.0718(12)$ \\
\hline N3 & $1.0316(5)$ & $0.7030(3)$ & $0.3478(2)$ & $0.0538(9)$ \\
\hline$H 3^{\prime}$ & 0.997609 & 0.753084 & 0.391490 & $0.065^{\star}$ \\
\hline N4 & $1.1458(5)$ & $0.9091(3)$ & $0.3548(3)$ & $0.0614(10)$ \\
\hline 01 & $0.8270(7)$ & $0.7863(4)$ & $0.0357(3)$ & $0.1122(16)$ \\
\hline 02 & $1.2059(5)$ & $0.6831(3)$ & $0.1943(3)$ & 0.0941 (13) \\
\hline S1 & $0.54357(15)$ & $0.79815(11)$ & $0.41849(8)$ & $0.0582(4)$ \\
\hline S2 & $0.70671(16)$ & $0.71049(10)$ & $0.51002(8)$ & $0.0572(4)$ \\
\hline $\mathrm{C} 1$ & $0.6675(6)$ & $0.9025(4)$ & $0.3295(3)$ & 0.0534 (11) \\
\hline $\mathrm{C} 2$ & $0.6883(7)$ & $1.0132(4)$ & $0.3573(4)$ & $0.0672(13)$ \\
\hline $\mathrm{H} 2$ & 0.643264 & 1.029291 & 0.423095 & $0.081^{*}$ \\
\hline C3 & $0.7743(7)$ & $1.0987(5)$ & $0.2886(4)$ & $0.0756(15)$ \\
\hline H3 & 0.785486 & 1.172740 & 0.307529 & $0.091^{*}$ \\
\hline $\mathrm{C} 4$ & $0.8438(7)$ & $1.0744(5)$ & $0.1919(4)$ & 0.0714 (14) \\
\hline $\mathrm{H} 4$ & 0.902745 & 1.132176 & 0.145583 & $0.086^{*}$ \\
\hline $\mathrm{C} 5$ & $0.8274(6)$ & $0.9656(4)$ & $0.1626(3)$ & 0.0609 (12) \\
\hline H5 & 0.875053 & 0.950463 & 0.096787 & $0.073^{*}$ \\
\hline C6 & $0.7399(6)$ & $0.8781(4)$ & $0.2308(3)$ & $0.0510(11)$ \\
\hline $\mathrm{C} 7$ & $0.7597(7)$ & $0.7257(5)$ & $0.1128(4)$ & $0.0683(13)$ \\
\hline $\mathrm{C} 8$ & $0.7114(7)$ & 0.6009 (4) & $0.1161(4)$ & 0.0624 (12) \\
\hline $\mathrm{C9}$ & $0.7419(7)$ & $0.5429(5)$ & $0.0286(4)$ & $0.0732(14)$ \\
\hline $\mathrm{C} 10$ & $0.6893(9)$ & $0.4266(6)$ & $0.0439(5)$ & 0.0928 (19) \\
\hline $\mathrm{H} 10$ & 0.706046 & 0.384018 & -0.011033 & $0.111^{*}$ \\
\hline C11 & $0.6149(9)$ & $0.3740(6)$ & $0.1356(6)$ & $0.097(2)$ \\
\hline $\mathrm{H} 11$ & 0.580265 & 0.296503 & 0.144218 & $0.116^{*}$ \\
\hline C12 & $0.5915(8)$ & $0.4382(5)$ & $0.2167(4)$ & $0.0835(16)$ \\
\hline $\mathrm{H} 12$ & 0.541239 & 0.402251 & 0.280347 & 0.100 * \\
\hline C13 & $0.8273(10)$ & $0.5978(6)$ & $-0.0750(4)$ & $0.110(2)$ \\
\hline $\mathrm{H} 13 \mathrm{~A}$ & 0.831778 & 0.542691 & -0.122594 & $0.165^{*}$ \\
\hline $\mathrm{H} 13 \mathrm{~B}$ & 0.943163 & 0.613764 & -0.075150 & $0.165^{*}$ \\
\hline $\mathrm{H} 13 \mathrm{C}$ & 0.761290 & 0.672054 & -0.093152 & $0.165^{*}$ \\
\hline C14 & $0.8085(6)$ & $0.5824(4)$ & $0.4495(3)$ & $0.0490(10)$ \\
\hline C15 & $0.7402(6)$ & $0.4719(4)$ & $0.4800(3)$ & $0.0575(12)$ \\
\hline $\mathrm{H} 15$ & 0.641084 & 0.465493 & 0.531268 & 0.069 * \\
\hline C16 & $0.8191(7)$ & $0.3712(4)$ & $0.4345(4)$ & $0.0629(12)$ \\
\hline $\mathrm{H} 16$ & 0.775195 & 0.296642 & 0.455838 & $0.076^{*}$ \\
\hline $\mathrm{C} 17$ & $0.9627(6)$ & $0.3826(4)$ & $0.3576(4)$ & $0.0611(12)$ \\
\hline $\mathrm{H} 17$ & 1.012461 & 0.315849 & 0.324980 & $0.073^{*}$ \\
\hline C18 & $1.0348(6)$ & $0.4901(4)$ & $0.3277(3)$ & 0.0559 (11) \\
\hline $\mathrm{H} 18$ & 1.134389 & 0.494795 & 0.276634 & $0.067^{\star}$ \\
\hline C19 & $0.9592(6)$ & $0.5924(4)$ & $0.3734(3)$ & $0.0493(10)$ \\
\hline $\mathrm{C} 20$ & $1.1469(6)$ & $0.7423(4)$ & $0.2644(3)$ & 0.0559 (11) \\
\hline $\mathrm{C} 21$ & $1.1947(6)$ & $0.8672(4)$ & $0.2649(3)$ & 0.0527 (11) \\
\hline $\mathrm{C} 22$ & $1.2820(6)$ & $0.9350(4)$ & $0.1781(3)$ & 0.0579 (12) \\
\hline $\mathrm{C} 23$ & $1.3214(6)$ & $1.0475(5)$ & $0.1901(4)$ & 0.0724 (14) \\
\hline $\mathrm{H} 23$ & 1.379576 & 1.095328 & 0.134613 & $0.087^{\star}$ \\
\hline $\mathrm{C} 24$ & $1.2765(7)$ & $1.0902(4)$ & $0.2820(4)$ & 0.0715 (14) \\
\hline $\mathrm{H} 24$ & 1.305139 & 1.165410 & 0.289570 & $0.086^{*}$ \\
\hline $\mathrm{C} 25$ & $1.1884(7)$ & $1.0185(4)$ & $0.3621(4)$ & $0.0673(13)$ \\
\hline $\mathrm{H} 25$ & 1.156608 & 1.047116 & 0.424353 & $0.081^{*}$ \\
\hline $\mathrm{C} 26$ & $1.3245(8)$ & $0.8923(5)$ & $0.0747(4)$ & 0.0847 (17) \\
\hline $\mathrm{H} 26 \mathrm{~A}$ & 1.414779 & 0.826687 & 0.072271 & $0.127^{\star}$ \\
\hline
\end{tabular}

Table 2: (continued)

\begin{tabular}{rrrrr}
\hline Atom & $\boldsymbol{x}$ & $\boldsymbol{y}$ & $\boldsymbol{z}$ & $\boldsymbol{U}_{\text {iso }} / \boldsymbol{U}_{\text {eq }}$ \\
\hline $\mathrm{H} 26 \mathrm{~B}$ & 1.362995 & 0.957700 & 0.024447 & $0.127^{*}$ \\
$\mathrm{H} 26 \mathrm{C}$ & 1.222498 & 0.865556 & 0.062098 & $0.127^{*}$ \\
\hline
\end{tabular}

layer chromatography. After the reaction was completed, the reaction mixture was concentrated to remove the THF and then extracted into ethyl acetate. The organic layer was dried over sodium sulfate and was concentrated under vacuum, to get crude solid, which was recrystallized from chloroform-acetonitrile to get diffraction-quality crystals. Yield $72 \%$. Anal. Calc. for $\mathrm{C}_{26} \mathrm{H}_{22} \mathrm{~N}_{4} \mathrm{O}_{2} \mathrm{~S}_{2}$ : C, 64.18; H, 4.56; N, 11.51; S, 13.18; found: C, 64.37; H 4.32; N 11.48; S, 13.15.

\section{Experimental details}

Hydrogen atoms were assigned with common isotropic displacement factors $U_{\text {iso }}(\mathrm{H})=1.2$ times $U_{\text {eq }}$ (C, benzene ring; $\mathrm{N}$, amide) and $U_{\text {iso }}(\mathrm{H})=1.5$ times $U_{\text {eq }}(\mathrm{C}$, methyl carbon). All the $\mathrm{H}$ atoms were refined as riding on their parent atom.

\section{Comment}

In nature, disulfide compounds have received much attention in the field of coordination chemistry, pharmaceutical chemistry, biochemistry, and organic synthesis [3-5]. It is particularly noteworthy that the disulfide bonds played an important role in the areas of folding, structure, and stability of the proteins because the S-S bonds are the only readily reversible covalent chemical cross-linking bonds presented in the native proteins $[6,7]$. Consequently, the syntheses of new disulfide compounds has become a hot spot. For instance, Sobczak et al. firstly described that the heterodimeric product 1-[(4-chlorophenyl)disulfanyl]-2-nitrobenzene was synthesized by the reaction of bis 4-chlorophenyl disulfide $\left[(4-\mathrm{ClPhS})_{2}\right]$ and bis 2-nitrophenyl disulfide [(2- $\left.\left.\mathrm{NO}_{2} \mathrm{PhS}\right)_{2}\right]$ [8]. Singh's group synthesized three hexadentate disulfide ligands and tested their performance for binding with library of metal ions [9]. So far, despite some thrilling work has been achieved, newly designed disulfide compounds are longsought-after yet still unmet. 
The molecular structure of the title disulfide compound is shown in the figure. Single crystal X-ray diffraction analysis reveals that the title structure consists of one diphenyl disulfide unit and two (6'-methylpyridine)2-carboxamide units, in two halves of the molecule (about $\mathrm{S}-\mathrm{S}$ bond) the phenyl ring and the substituted pyridine are forming very different dihedral angles (31.91(2); 6.60(2) $\left.{ }^{\circ}\right)$ between the phenyl plane $(\mathrm{C} 14 / \mathrm{C} 15 / \mathrm{C} 16 / \mathrm{C} 17 / \mathrm{C} 18 / \mathrm{C} 19)$ and the pyridine plane $(\mathrm{C} 21 / \mathrm{C} 22 / \mathrm{C} 23 / \mathrm{C} 24 / \mathrm{C} 25 / \mathrm{N} 4)$ and the phenyl plane $(\mathrm{C} 1 / \mathrm{C} 2 / \mathrm{C} 3 / \mathrm{C} 4 / \mathrm{C} 5 / \mathrm{C} 6)$ and the pyridine plane (C8/C9/C10/C11/C12/N2), respectively, suggesting that one-half is relatively more planar than the other. The torsion angle $\mathrm{C} 1-\mathrm{S} 1-\mathrm{S} 2-\mathrm{C} 14$ is $90.32^{\circ}$ in the molecular structure of the title compound and shows a kink around the S-S bond making the two halves out of plane with each other. The bond distance of $\mathrm{S}-\mathrm{S}$ is $2.0758(17) \AA$, which is similar with that of the reported $N, N^{\prime}$-(disulfanediyl-bis(4-(morpholin-4-yl)-2,1-phenylene)) bis(1,3-benzothiazol-2-amine) chloroform solvate [10]. Additionally, the title compound adopts weak $\pi \cdots \pi$ interactions between the pyridine ring (C21/C22/C23/C24/C25/N4) and phenyl ring (C1/C2/C3/C4/ C5/C6) with a centroid to centroid distance as $3.83 \AA$, which was similar to that of the reported $N, N^{\prime}$-(disulfanediyldi2,1-phenylene)dipyridine-2-carboxamide [11].

Author contributions: All the authors have accepted responsibility for the entire content of this submitted manuscript and approved submission.

Research funding: This study was funded by Liaocheng University Doctoral Foundation (318051437).

Conflict of interest statement: The authors declare no conflicts of interest regarding this article.

\section{References}

1. Bruker. APEX2, SAINT and SADABS; Bruker AXS Inc.: Madison, Wisconsin, USA, 2004.

2. Sheldrick G. M. Crystal structure refinement with SHELXL. Acta Crystallogr. 2015, C71, 3-8.

3. Ballesteros M., Tsui E. Y. Reactivity of zinc thiolate bonds: oxidative organopolysulfide formation and S3 insertion. Inorg. Chem. 2019, 58, 10501-10507.

4. Huang X., Rong N., Li P., Shen G., Li Q., Xin N., Cui C., Cui J., Yang B., Li D., Zhao C., Dou J., Wang B. AIBN-promoted synthesis of bibenzo[b] $[1,4]$ thiazines by the condensation of 2,2'- dithiodianiline with methyl aryl ketones. Org. Lett. 2018, 20, 3332-3336.

5. Meinhold D., Beach M., Shao Y., Osuna R., Colon W. The location of an engineered inter-subunit disulfide bond in factor for inversion stimulation (FIS) affects the denaturation pathway and cooperativity. Biochemistry 2006, 45, 9767-9777.

6. Jacob C., Giles G. L., Giles N. M., Sies H. Sulfur and selenium: the role of oxidation state in protein structure and function. Angew. Chem. Int. Ed. 2003, 42, 4742-4758.

7. Gupta A., Van Vlijmen H. W. T., Singh J. A classification of disulfide patterns and its relationship to protein structure and function. Protein Sci. 2004, 13, 2045-2058.

8. Sobczak S., Drozdz W., Lampronti G. I., Belenguer A. M., Katrusiak A., Stefankiewicz A. R. Dynamic covalent chemistry under highpressure: a new route to disulfide metathesis. Chem. Eur J. 2018, 24, 8769-8773.

9. Raj P., Singh A., Kaur K., Aree T., Singh A., Singh N. Fluorescent chemosensors for selective and sensitive detection of phosmet/ chlorpyrifos with octahedral $\mathrm{Ni}^{2+}$ complexes. Inorg. Chem. 2016, 55, 4874-4883.

10. Esmaili R., Nematollahi D. Electrochemical method for the synthesis of disulfides of 2-(benzo[d]thiazol(oroxazol)-2-ylamino)5-morpholinobenzenethiol. J. Org. Chem. 2013, 78, 5018-5021.

11. Lumb I., Hundal M. S., Hundal G. Copper(II)-catalyzed disulfide scission-stepwise aerobic oxidative cleavage to sulfinate and sulfonate and reductive anaerobic cleavage to thiols. Inorg. Chem. 2014, 53, 7770-7779. 